\title{
Infection with influenza and parainfluenza viruses in chronic bronchitis
}

\author{
J. E. STARK, R. B. HEATH, AND M. P. CURWEN \\ From the Virus Laboratory, Department of Bacteriology and the Department of Medical \\ Statistics, St. Bartholomew's Hospital, London
}

Exacerbations of chronic bronchitis are often preceded by symptoms of infection of the upper respiratory tract, but little is known of the frequency with which they are precipitated by virus infections. There is evidence that bronchitics develop severe illness when infected with influenza A virus (Tyrrell, 1952 ; Walker, Douglas, Leckie, Pines, and Grant, 1958; Louria, Blumenfeld, Ellis, Kilbourne, and Rogers, 1959) and that the features of the influenzal illness may be modified by the pre-existing chronic bronchitis. Hennessy (1962) and Jack and Gandevia (1960) failed to demonstrate a viral aetiology for the exacerbations of bronchitis in the patients they studied. More recently, Sommerville (1963) found serological evidence of infection with respiratory syncytial virus in bronchitics in exacerbation. Carilli, Gohd, and Gordon (1964) obtained evidence of infection with many respiratory viruses, including influenza and parainfluenza, during a six-month study of $\mathbf{3 0}$ bronchitics. However, both virus infections and exacerbations of bronchitis are common occurrences, and some studies, such as that of Carilli et al. (1964), though demonstrating a high incidence of virus infections in bronchitics, have not shown that such infections are more frequent at the time of exacerbation.

The parainfluenza viruses were first isolated from children with acute respiratory disease in 1955 and 1957, and the clinical syndromes associated with them in childhood have been well defined (Parrott, Vargosko, Luckey, Kim, Cumming, and Chanock, 1959). They probably account for a high proportion of all acute respiratory infections of children, but less is known of the frequency and effect of infection in adults. In most cases a mild upper respiratory illness seems to occur, but acute bronchitis and pneumonia have been reported (Evans, 1960; Evans and Brobst, 1961).

In this investigation we have tried to assess the importance of the influenza and parainfluenza viruses in causing acute illness among a group of typical chronic bronchitics during the winter of 1961-62.

\section{MATERIALS AND METHODS}

CLINICAL Eight chest physicians ${ }^{1}$ in charge of clinics in and around London selected patients for inclusion in the study and were responsible for their clinical assessment and treatment. In order to qualify for inclusion patients must have had cough with sputum for three months or more during each of the previous two years. Frank asthmatics and patients with dominant bronchiectasis or pulmonary tuberculosis were excluded.

Two hundred and sixteen patients were enrolled between September and November 1961 and were seen finally in April 1962. At the first visit a serum sample was obtained. Arrangements were made for the patients to be seen every four weeks throughout the winter. At each attendance a further serum sample was obtained and a record was made of the dates of onset of any exacerbations of bronchitis or upper respiratory infections which had occurred since the previous visit. An exacerbation was arbitrarily defined as any deterioration of respiratory symptoms.

The conventional technique of serological diagnosis by titration of acute sera (taken almost immediately) and convalescent sera (taken two to three weeks later) could not be used without disruption of the routine of the clinics, hence sera were collected when the patients attended for their monthly appointments. An assessment of the relationship between virus infections and illnesses was thereby made more difficult but the method had the advantage of revealing asymptomatic infections.

LABORATORY Sera were sent by post to the laboratory and were then stored at $-20^{\circ}$ C. They were subsequently titrated against the following antigens:

Influenza A ; soluble antigens.

Parainfluenza 1-Cop 222 strain of H.A. 2 (Birkum Petersen and Magnus, 1958).

K. M. Citron, P. D. B. Davies, J. A. Keeping, P. J. Lawther, N. C. Oswald, D. L. Pugh, E. G. Sita Lumsden, W. D. R Thompson 
Parainfluenza 2-Croup associated virus (Chanock, 1956).

Parainfluenza 3-Mills strain of H.A.1 (Cook, Andrews, Fox, Turner, James, and Chanock, 1959).

Parainfluenza viruses were propagated in monkey kidney tissue culture and the culture fluid was used as an antigen. Influenza virus soluble antigens were obtained from the Public Health Laboratory Service, Colindale.

Complement fixation tests were carried out in plastic plates using $\mathbf{0 . 1} \mathrm{ml}$. volumes of inactivated serum, complement, and antigen ; 2.5 M.H.D. of complement were used, and fixation of reagents took place at $4^{\circ} \mathrm{C}$. overnight. Sensitized sheep cells $(2 \%), 0.1 \mathrm{ml}$, was added and lysis was allowed to occur for 30 minutes at $30^{\circ} \mathrm{C}$. Results were read after standing the plates for one hour at $4^{\circ} \mathrm{C}$.

Haemagglutination-inhibition tests were also carried out in plastic plates by a method previously described (Heath, Tyrrell, and Peto, 1962).

All the sera from each patient were titrated against a virus on the same day using the same pool of virus and the same red cells. In all serological studies a fourfold or greater rise of antibody level was considered to be diagnostic of infection.

\section{RESULTS}

Seventeen patients attended only once and were excluded from the analysis. The remaining 199 comprised 154 men and 45 women. The average age of the men was $61 \cdot 1$ years and of the women $53 \cdot 1$ years. Their ages ranged from 20 to 79 years. The average period of observation (between first and last attendances) was $19 \cdot 2$ weeks, and most patients were seen four or five times during the winter. Some ceased to attend early in the investigation and others were seen infrequently or at long intervals because of illness or because they were unable to visit the clinic in unfavourable weather.

Of the 199 patients, 67 suffered no exacerbation of bronchitis whilst under observation, 74 had one and 58 two or more. Eighty-four patients reported no upper respiratory infection, 66 a single episode, and 49 two or more.

Serological tests revealed 23 virus infections. Of these, 13 were due to influenza $B$. There was no evidence of infection with influenza $A$. Of the 10 antibody rises against parainfluenza viruses, seven were against parainfluenza virus 3 , and two were against parainfluenza 1 . One patient showed an equal rise of antibody against parainfluenza 1 and 2 viruses. In view of the known lack of specificity of serological tests for parainfluenza infections (Chanock, Wong, Huebner, and Bell, 1960), the member of the group responsible for each infec-
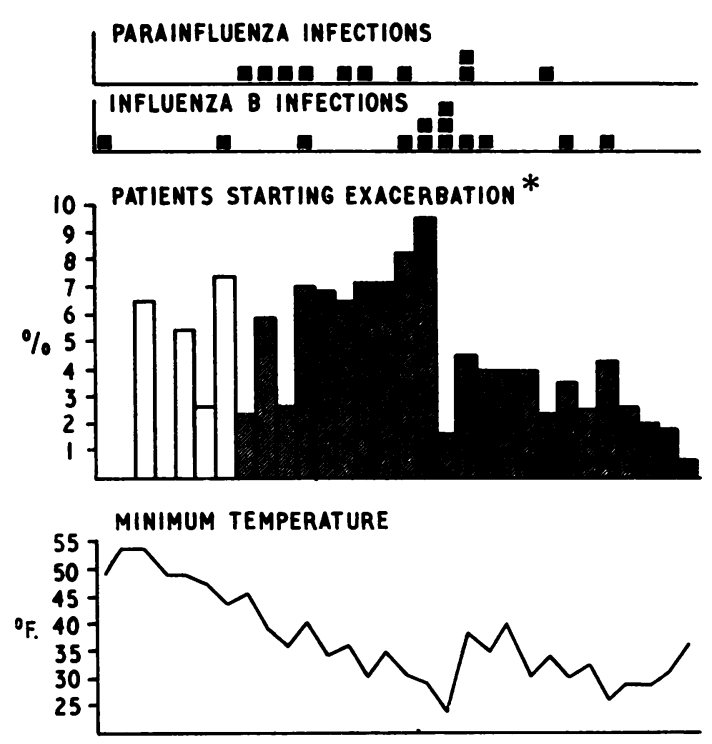

ig./m.3 MAXIMUM CONCENTRATION OF

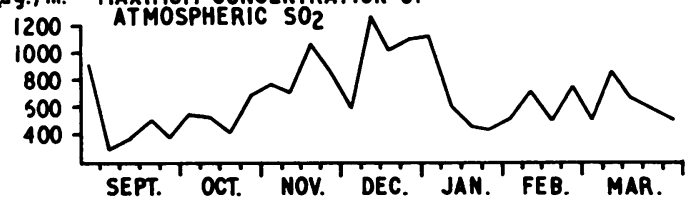

FIGURE. Distribution of exacerbations of bronchitis and of virus infections during the winter 1961-62.

*Percentages are based on the number of patients under observation in each week. Unshaded areas represent percentages based on fewer than 100 patients.

tion was uncertain; for this reason all parainfluenza infections were considered together.

The Figure shows the time distribution of exacerbations of bronchitis and of virus infections and the prevailing air temperature and concentrations of sulphur dioxide. There was a fairly even distribution of exacerbations and of virus infections throughout the winter with a slight peak at a time when temperatures were low and atmospheric pollution was relatively high.

For the purpose of analysis the period of observation of each patient can be divided into 'intervals', each interval being the period between successive attendances at which serum was obtained. There were 908 such intervals, of which $613(68 \%)$ were of four weeks' duration, $163(18 \%)$ of five weeks' duration, and the remainder of longer or shorter duration.

Because a time-lag of about a week occurs between infection and a diagnostic rise of antibody level, an interval was arbitrarily defined as 
'containing' an exacerbation of bronchitis or an upper respiratory infection when the onset of symptoms fell between a date one week before one visit and another date one week before the next visit. The intervals can then be classified into three types: those containing an exacerbation (whether or not preceded by an upper respiratory infection), those containing an upper respiratory infection but no exacerbation, and those containing no respiratory illness.

Table I shows that of the 23 virus infections 13 were associated with an exacerbation of bronchitis, four with upper respiratory infections, and six were apparently asymptomatic. Virus infections were relatively more frequent in intervals containing a respiratory illness.

\section{T A B L E I}

ASSOCIATION OF INFLUENZA B AND PARAINFLUENZA VIRUS INFECTIONS WITH RESPIRATORY ILLNESSES

\begin{tabular}{c|c|c|c}
\hline Intervals Containing & $\begin{array}{c}\text { No. of } \\
\text { Intervals }\end{array}$ & $\begin{array}{c}\text { Intervals Containing an } \\
\text { Infection with }\end{array}$ \\
\cline { 3 - 4 } & $\begin{array}{c}\text { Influenza } \\
\text { B }\end{array}$ & $\begin{array}{c}\text { Para- } \\
\text { influenza }\end{array}$ \\
\hline $\begin{array}{c}\text { Exacerbations (with or with- } \\
\text { out upper respiratory in- } \\
\text { fection) . }\end{array}$ & 185 & $9(4.9 \%)$ & $4(2 \cdot 2 \%)$ \\
$\begin{array}{c}\text { Upper respiratory infections } \\
\text { (without exacerbations) }\end{array}$ & 68 & $1(1.5 \%)$ & $3(4 \cdot 4 \%)$ \\
No respiratory illness & 655 & $3(0 \cdot 5 \%)$ & $3(0 \cdot 5 \%)$ \\
\hline & 908 & 13 & 10 \\
\hline
\end{tabular}

There is, however, a possible source of bias arising out of the variable lengths of the intervals. A longer interval is inherently more likely to contain both a virus infection and a respiratory illness even if the two are causally unrelated. In Table II only the intervals of four weeks' duration are considered. The proportion of virus infections seems to follow a trend, being lowest for the

T A B LE II

ASSOCIATION OF INFLUENZA B AND PARAINFLUENZA INFECTIONS WITH RESPIRATORY ILLNESSES DURING INFECTIONS WITH RESPIRATORY ILLN
FOUR-WEEK INTERVALS

\begin{tabular}{|c|c|c|c|}
\hline \multirow{2}{*}{ Intervals Containing } & \multirow{2}{*}{$\begin{array}{l}\text { No. of } \\
\text { Intervals }\end{array}$} & \multicolumn{2}{|c|}{$\begin{array}{l}\text { Intervals Containing an } \\
\text { Infection with }\end{array}$} \\
\hline & & $\underset{B}{\text { Influenza }}$ & $\begin{array}{c}\text { Para- } \\
\text { influenza }\end{array}$ \\
\hline $\begin{array}{l}\text { Exacerbations (with or with- } \\
\text { out upper respiratory ill- } \\
\text { ness) }\end{array}$ & 99 & $6(6 \cdot 1 \%)$ & $3(3 \cdot 0 \%)$ \\
\hline $\begin{array}{l}\text { Upper respiratory infections } \\
\text { (without exacerbations).. } \\
\text { No respiratory illness } \quad . .\end{array}$ & $\begin{array}{r}36 \\
478\end{array}$ & $\begin{array}{l}1(2 \cdot 8 \%) \\
2(0.4 \%)\end{array}$ & $\begin{array}{l}1(2 \cdot 8 \%) \\
3(0 \cdot 6 \%)\end{array}$ \\
\hline Total & 613 & 9 & 7 \\
\hline Significance of trend ${ }^{1}{\underset{\mathbf{P}}{2}}_{\mathbf{P}} \ldots$ & - & $\begin{array}{l}18.5 \\
<0.001\end{array}$ & $\begin{array}{l}4.8 \\
<0.05\end{array}$ \\
\hline
\end{tabular}

' By the method of Armitage (1955) intervals containing no respiratory illness and highest for the intervals containing exacerbations of bronchitis. In fact influenza $B$ infections occurred more than 10 times more frequently in intervals containing exacerbations than in other intervals with no illness.

\section{DISCUSSION}

It is impossible to be dogmatic about the statistical significance of these findings, since not only is the number of virus infections small but the intervals are not strictly speaking statistically independent. It seems reasonable, however, to test for the significance of the trend of percentages by the method of Armitage (1955). This analysis shows (Table II) that the trend for influenza $B$ infections was most unlikely to have occurred by chance $(\mathrm{P}<0.001)$. The trend for parainfluenza infections is of borderline significance $(P<0.05)$.

A relationship such as that shown between virus infections and respiratory illnesses does not, of course, prove that the two are causally related. It might arise if there were a subgroup of patients or of intervals with a high proportion of illnesses and, for some unconnected reason, a large number of virus infections. Infections were not confined to a few clinics, having occurred in six of the eight, and men and women of all ages were involved. The parainfluenza infections were evenly distributed throughout the winter (Figure). However, eight of the 13 influenza $B$ infections occurred within a six-week period in December and January. Further analysis has shown that infections bore the same proportional relationship to exacerbations during this six-week period as during the whole winter. The findings suggest that a small but definite proportion of exacerbations of chronic bronchitis are the result of infection with influenza $B$ and parainfluenza viruses.

The association of influenza $B$ infections with exacerbations of bronchitis is similar to the experience of Tyrrell (1952) and Stuart-Harris, Pownall, Scothorne, and Franks (1953) with influenza $\mathbf{A}$ infections. The use of vaccines, with a view to preventing influenzal infection of bronchitics, would therefore appear to be justified, particularly when it is anticipated that influenza will be epidemic.

The parainfluenza infections are of interest in that there are few reports of infection of older adults. The number of infections in this study is almost certainly an underestimate because adults, most of whom possess antibodies against the parainfluenza viruses (Heath et al., 1962), may be 
reinfected without developing a further rise of antibody (Bloom, Johnson, Jacobsen, and Chanock, 1961). In this study parainfluenza infection was less likely than influenza to be followed by an exacerbation of bronchitis.

There are many other factors which contribute to exacerbations of bronchitis ; in our experience the greatest number of exacerbations occurred at the time of high atmospheric pollution and low temperature. We were able to attribute $7 \%$ at most to influenza and parainfluenza infections. A truer estimate of the full significance of virus infections in chronic bronchitis must await studies of other respiratory viruses such as adenovirus, respiratory syncytial virus, and, perhaps most important of all, the rhinoviruses.

\section{SUMMARY}

The relationship between exacerbations of chronic bronchitis and infection with influenza and parainfluenza viruses was studied in a group of 199 chronic bronchitics. These patients experienced 13 infections with influenza $B$ virus and 10 with parainfluenza viruses.

There is strong evidence that a small number of exacerbations were caused by influenza $B$ virus infection. Parainfluenza virus infections appeared to have a similar effect in causing exacerbations, but the evidence is less conclusive.
We are grateful to Miss Cynthia Dixon for her technical assistance.

\section{REFERENCES}

Armitage, P. (1955). Tests for linear trends in proportions and frequencies. Biometric $s, 11,375$.

Birkum Petersen, K., and Magnus, P. von (1958). Isolation of a new virus from a child with an influenza-like disease. Dan. med. Bull., $5,157$.

Bloom, H. H. Johnson, K. M. Jacobsen, R., and Chanock, R. M. (1961). Recovery of parainfluenza viruses from adults with upper respiratory illness. Amer.J. Hyg., 74, 50.

Carilli, A. D., Gohd, R. S., and Gordon, W. (1964). A virologic study of chronic bronchitis. New Engl.J. Med., 270, 123.

Chanock, R. M. (1956). Association of a new type of cytopathogenic myxovirus with infantile croup. J. exp. Med., 1u4, 555 Werologic response of individuals infected with parainfluenza viruses. Amer. J. publ. Hlth, 50, 1858 .

Amer. J. publ. Hlth, 50, 1858.
Cook, M. K., Andrews, B. E., Fox, H. H., Turner, H. C., James, W. D., and Chanock, R. M. (1959). Antigenic relationships among the "newer" myxoviruses (parainfluenza). Amer. J. Hyg., 69, 250.

Evans, A.S. (1960). Infections with hemadsorption virus in University of Wisconsin students. New Ergl. J. Med., 263, 233.

and Brobst, M. (1961). Bronchitis, pneumonitis and pnetmonia in University of Wisconsin students. Ibid., 265, 401 .

Heath, R. B., Tyrrell, D. A. J., and Peto, S. (1962). Serological studies with Sendai virus. Brit. J. exp. Path., 43, 444.

Hennessy, A. V. (1962). An attempt to demonstrate a viral etiology for chronic bronchitis. Amer. Rev. resp. Dis., 86, 350.

Jack, I., and Gandevia, B. (1960). Virus studies in chronic bronchitis. Ibid., 82, 482 .

Louria, D. B., Blumenfeld, H. L., Ellis, J. T., Kilbourne, E. D., and Rogers, D. E. (1959). Studies on influenza in the pandemic of 1957-1958. II. Pulmonary complications of influenza. J. clin. Invest., 38, 213.

Parrott, R. H., Vargosko, A., Luckey, A., Kim, H. W., Cumming, C., and Chanock, R. (1959). Clinical features of infection with hemadsorption viruses. New Engl. J. Med., 260, 731.

Sommerville, R. G. (1963). Respiratory syncytial virus in acute exacerbations of chronic bronchitis. Lancet, $2,1247$.

Stuart-Harris, C. H., Pownall, M., Scothorne, C. M., and Franks, Z. (1953). The factor of infection in chronic bronchitis. Quart.J. Med., n.s. 22, 121 .

Tyrrell, D. A. J. (1952). The pulmonary complications of influenza as seen in Sheffield in 1949. Quart. J. Med., n.s. 21, 291.

Walker, W. C. Douglas, A. C., Leckie, W. J. H. Pines, A., and Grant, I. W. B. (1958). Respiratory ccmplications of influenza. Lancet, 1, 449. 